\title{
The convergence of public opinion and interest group lobbying and the disruption of the Trump administration in United States immigration policy
}

\author{
Jaeyeon Joo
}

This article explores the power and influence of interest groups and public opinion in configuring the immigration policy direction in the United States and discusses how the pro-immigrant consensus between the two entities was disrupted by the Trump administration. As interest groups have been traditionally a pro-immigrant party due to the economic benefits immigration brings to certain sectors of business, notably the agricultural and high technology industries, it has remained at odds with the moderately anti-immigrant U.S. public for many years. Recently, however, these two previously divergent entities have been converging into a pro-immigrant (in aggregate) position as the public grew more favorable of immigration in recent years. In this light, we trace this convergence of public opinion and interest group lobbying and then examine how the Trump administration has disrupted this seemingly harmonious trend in order to push through a series of anti-immigration policies that in essence represent the minority view in the United States. We further show how the growing polarization between the anti- and pro-immigrant public created an opening for Trump to exploit: capturing just enough support to win the election regardless of general public sentiment and interest group lobbying.

Key Words: Immigration policy, Trump, Public opinion, Interest groups, Election

\section{INTRODUCTION}

President Donald J. Trump has campaigned and governed on the premise that

* Jaeyeon Joo (jaeyeonjoo92@yonsei.ac.kr) is a candidate for a Master's Degree in Political Science at Yonsei University. Majoring in comparative politics and American politics, her research focuses on migration and immigration studies surrounding the institutional and legal aspects of these issues in the United States and East Asia. 
immigration has spiraled out of control and poses a grave national security risk to the United States, and that unauthorized crossings across the land border with Mexico translate into a national emergency. It is Trump's defining issue, even more so than his pledges to roll back international trade agreements, and he has become all the more strident on immigration in his two years thus far as president. Yet Trump's position on immigration flies in the face of the balance of American public opinion as well as the prevailing consensus among interest groups in Washington. Remarkably, Trump has catapulted immigration to the front burner of American politics at precisely the moment when interest groups and public opinion have converged in a way that is quite supportive of immigration, as well as a period in which unauthorized entries into the United States have been steadily declining. We, therefore, trace this convergence of public opinion and interest group lobbying and then examine how Trump has disrupted this seemingly harmonious trend in order to push through a series of anti-immigration policies that in essence represent the minority view in the United States. We further show how growing polarization in American politics and society created an opening for Trump to exploit; that he was able to capture just enough support from precisely the segment of the public he needed first to win the election and then to initiate restrictive immigration policies that in essence does not represent the majority view of the American people.

\section{FACTORS INFLUENCING U.S. IMMIGRATION POLICY: INTER- EST GROUPS VS. PUBLIC OPINION}

\section{WHY INTEREST GROUPS MATTER}

Immigration is an inherently complex phenomenon as it cuts across domestic politics and global affairs. The general public and key interest groups are sensitive and responsive to immigration policies, as this can impact the well-being of families and the operations and profits of businesses, while international circumstances can drive closure and fear in domestic politics rather than openness toward immigrants. These aspects of immigration politics diversify the factors affecting policy direction, from public opinion to interest groups and political elites. Yet, the post-World War II evaluation on the leverage of public opinion in shaping foreign policies have been generally skeptical, with many scholars and political elites discounting the importance of mass public opinion. Led by the realist tradition of differentiating foreign policy from others, the Almond-Lippmann Consensus has circumscribed the public as highly 
volatile and incoherent, having little if any impact on foreign policy. (Almond 1950; Lippmann 1955; Holsti 1992)

For many years scholars wrote off the public as largely irrelevant to policymaking, since public opinion lacks an organized or sustained structure. Likewise, prominent models explaining the forces influencing immigration policies have emphasized elite decisions and bargaining amongst powerful interest groups regardless of public sentiment. The prevailing scholarly explanation on immigration policymaking has focused on the economic and political benefits immigration brings to certain sectors of the economy, (Tichenor 2002; Wong 2006; Facchini et al. 2011;) such as agricultural businesses dependent on cheap immigrant labor, high-tech industries hiring temporary immigrant workers, which thereby bring benefits to specific 'clienteles' profiting from immigrant labor and votes. (Ronger and Gunes-Ayata 1994) Such elitecentered models of policymaking have provided a key explanation for the expansionary immigration agenda the United States has followed since 1965. (Sobczak 2010)

The clientelist model underlines the prominence of interest groups and political elites because the benefits of immigration are concentrated heavily within businesses that employ immigrant labor as well as political parties and organizations that earn support from the immigrants. (Freeman 1995) Conversely, the model marginalizes the influence of mass opinion on the assumption that public sentiment towards immigration is largely led by symbolic concerns rather than self-interest, lacking the motivations to mobilize. (Hainmueller and Hopkins 2014) Since the incentives for pro-immigration policies are concentrated on powerful economic and political interest groups, their organized and coherent lobbying positively impact the policymakers, leading U.S. immigration policies to accept and legalize more immigrants, continuing the trajectory of the 1965 Immigration and Naturalization Act. (Facchini et al. 2011, 115) Although a change in immigration policy was made in 1985 by the Reagan administration through passing the Immigration Reform and Control Act, which sought to prevent employers from hiring unauthorized immigrants, at the same time unauthorized immigrants were also given the opportunity to apply for permanent residency, opening up a pathway to legal status for approximately three million people. (Council on Foreign Relations n.d.)

How much do interest groups, especially industry-related groups and labor organizations, affect the course of immigration policy-making in the United States? To be sure, industries that depend heavily on immigrant workers lobby the government to relax border controls, increase temporary visa caps and in general push for a more open policy agenda. On the other hand, labor organizations and 
unions pressure the government to limit the entry of immigrants in an effort to safeguard wages and job security. (Williamson 2005) Williamson argues that as early as 1882, when the Chinese Exclusion Act was passed, labor unions campaigned to curb the number of immigrant workers while industries campaigned for an increase. (Williamson 2005, 30) Studies on the impact of business interest groups on immigration policies have found a positive correlation between lobbying expenditure on pro-immigration policies and the increase of temporary visa allocation numbers. A study by Gordon H. Hanson and Antonio Spilimbergo showed that when industries (from apparel factories to slaughterhouses to farms growing fruits and vegetables) highly dependent on immigrant labor experiences an increase in the demand for these products, border enforcement is commonly relaxed in order to admit more undocumented immigrants. (Hanson and Spilimbergo 2011, 614) The number of hours U.S. Border Patrol officers spends on duty in the field has a negative correlation with relative price changes; in other words, when industry demand for undocumented labor is high, border enforcement falls. Hanson and Spilimbergo point to the political lobbying of interest groups as a possible if not definite reason leading to this correlation.

Because the level of border enforcement is raised when the overall U.S. labor market tightens, typically in light of expectations for an increase in unauthorized entries, the cause-and-effect relationship only applies to specific industries dependent on immigrants and the associated lobbying activities of the relevant interest groups. Furthermore, Facchini, Mayda and Mashira's statistical research on the influence of interest groups on immigration policy emphasized the role of businesses lobbying for Congress to increase the temporary visa cap in their respective sectors. Yet their findings also suggested that strong labor unions can decrease the number of visa caps, countering the pressure from interest groups from businesses. Through analyzing lobbying expenditures by industry sectors and targeted policy areas and comparing any increases in visa caps with the rate of union membership in each sector and its success in decreasing the visa caps, they have inferred that the barriers to migration are lower in business areas that spend more money lobbying than in areas where labor unions are more powerful. (Facchini et al. 2011, 120) They concluded that a 10 percent increase in lobbying expenditures per native worker by business groups, translates into three to five percent more visas per native worker, while a one percent increase in the union membership rate (assumed to be a proxy for lobbying expenditures by labor groups) is associated with a two to five percent lower number of visas per native worker.

These findings suggest that economic interest groups and labor unions hold considerable influence over United States immigration policy, tilting policies in an expansionary direction. The influence of economic factors in immigration 
policy is not surprising when considering that foreign-born workers, including legally-admitted immigrants, refugees, temporary residents, and temporary workers, plus undocumented immigrants, make up more than 17 percent of the total workforce in the United States. (Bureau of Labor Statistics 2018) These cases also illustrate the power of interest groups in utilizing existing policies to their benefit, such as policies that have the effect of allocating more immigrant workers to a specific business sector like the technology industry.

\section{WHY PUBLIC OPINION MATTERS}

In contrast with the interest group centered debate on immigration policy-making which downplays the power of public opinion as minimal, scholarship on public opinion and its relationship to immigration policy suggests that public preferences might influence policy directions through limiting policy choices, making it difficult to pass legislation that disrupts mass opinion. Such a shift toward the view that public opinion can contribute to the shaping of foreign policy, took place as the post-World War II consensus was challenged by Holsti and Rosenau. The public's intense disapproval of the military intervention by the United States in Vietnam and its dramatic influence on foreign policy elicited a new view among scholars that the general public not only accesses and digests information on foreign policy but also holds far more leverage than previous studies had indicated. (Holsti 1992, 43) Similarly, critics of an interest group or 'clientele' led models argue that public opinion on immigration policies is not only formulated within a set of coherent standards but also possibly has a greater influence on immigration policymaking than previous models have suggested. (Levy et al. 2016)

The general sentiment of the public can be described as "receptive to the idea of limited legalization" and containing far greater hostility toward unauthorized immigration than fully authorized immigration. (Wright et al. 2015, 230) Many studies have focused on perceived economic and socio-psychological threats as motivations behind public sentiment against immigration. (Merolla et al. 2013) These socioeconomic factors included massive losses of manufacturing jobs, the weakening of labor unions that helped provide workers with job security, the depletion of social welfare provisions, and changing ethnic and cultural characteristics in many local communities. Yet, relatively little has been studied on the extent public opinion pressures policymakers or if public opinion actually is at odds with current immigration policy trends.

Levy, Wright, and Citrin argue, against the popular assessment of strong and organized interest group pressure and weak and fickle public opinion, that the previous clientele-driven model has underestimated and minimized the role of public opinion in contemporary policy-making. They ask if the public were 
to be less accepting of policies favorably disposed toward immigrants, then would the industry groups have pushed a pro-immigration agenda anyway? They explain that the current commercial polling question on immigration is a simplified general question - which they refer to as a "level question" - that respondents are assumed to answer based on how they perceive the current level of immigration. The question reads as follows: "Do you think the number of immigrants from foreign countries who are permitted to come to the United States to live should be increased a lot, increased a little, left the same as it is now, decreased a little, or decreased a lot?" (Levy et al. 2016, 663) Those who state a preference for a decline in immigrants are regarded as 'restrictionist.'

However, when respondents were asked a different question specifically on which subcategory of immigration they desire to restrict, only 21 percent of respondents supported decreasing family-based immigration, 24 percent support decreasing skilled labor immigration, and 24 percent support decreasing the number of refugees admitted into the United States. (ibid., 666) These findings suggest that when the same question, in essence, is asked in more specific terms and in subcategories, the public is not necessarily at odds with an expansionary immigration agenda. Furthermore, although polling results indicate that more than half the American public would prefer to see a decline in immigration rather than an increase, it is tricky to draw conclusions regarding public opinion when considering that responses to general survey questions can be different from public perceptions on specific policy steps.

These findings offer two key insights about public opinion. First, the public is not so marginalized from immigration policy-making process that their severe disapproval on a certain policy direction still can constrain policy choices for political leaders. Second, in contrast with the established view that the American public is generally restrictive rather than accepting of immigration, recent research findings suggest that Americans are not exactly hostile toward immigration when taking into account specific categories and circumstances in which immigration occurs. This casts doubt upon past assumptions that defined Americans as 'restrictionists' (ibid., 668) and suggests that the public might be more approving of immigration when their perspectives are observed beyond a simple, sweeping 'level question.' Countering the clientele led model which focused on the power of interest groups and political elites shaping immigration policy in ways that suit their priorities, the public opinion centered account shows that mass preferences also contribute to the policy-making process and are also not at stark odds with the preferences of interest

1 In their study, a 'level question' refers to the current level of immigration "as an anchoring point, and an opinion is solicited about whether and how this status quo should be changed." 
groups, either.

\section{CURRENT INTEREST GROUP LOBBYING AND PUBLIC OPIN- ION ON IMMIGRATION}

Having established how interest groups and public opinion influence immigration policy in tandem, we turn to examine whether the recent restrictive immigration policies proposed by President Donald Trump - the withdrawal of the Deferred Action for Childhood Arrivals (DACA) program, the expansion and renovation to the existing border wall separating the United States and Mexico, and general immigration reform measures aimed at curbing unauthorized immigration - is in any meaningful way representative of the current consensus. Has the public actually become more restrictive towards immigration, with interest groups, for their part, less willing than before to invite skilled laborers to the United States? In order to examine if the two groups' preference on immigration policy has recently shifted toward more restrictive measures, we analyzed (1) the number of lobbying reports filed from corporate clients and labor unions, demanding the relaxation of immigration and (2) poll results concerning public preference on immigration.

Our findings suggest that interest groups - especially in the high-tech sector - continue to lobby strongly for expansionary immigration policies such as increasing the availability of the $\mathrm{H} 1 \mathrm{~B}$ visa and the $\mathrm{J} 1$ visa, as well as maintaining DACA, given how this initiative affects many of their employees. (Unites States Senate 2018) Labor unions, conventionally strong opponents to immigration, also growingly support policies that open doors to seasonal and temporary immigrant workforce and at times even lobby for pro-immigrant policies such as the retainment of DACA and the enhancement of Temporary Protected Status. (Unites States Senate 2019) Furthermore, the public seems to be responding more positively to immigration than before, diverging from the 'disconnect' interpretation that the general public has been exhibiting more hostility toward immigration than the balance of opinion among Washington interest groups. Now, the gap seems to lie between contrasting segments of the public itself.

\section{INTEREST GROUPS REMAIN STRONG ON EXPANSIONARY POLICIES} We draw upon information on lobbying compiled by the Center for Responsive Politics in Washington D.C., which collects each lobbying report submitted to the Office of the Clerk in the U.S. House of Representatives. (Center for Responsive Politics 2019; U.S. House of Representatives 2019) As shown in Figure 1, the number 
of lobbying reports on immigration and the number of clients have both increased dramatically over the past three decades. Report numbers have tripled from 1998 to 2008 and increased by another 30 percent in the most recent decade and now seems to have reached a plateau. More lobbying than ever is going on with immigration, and it is generally in favor of opening the United States to further immigration: the voices of immigration advocates have never been louder.

Figure 1. Annual number of lobbying clients and reports related to immigration

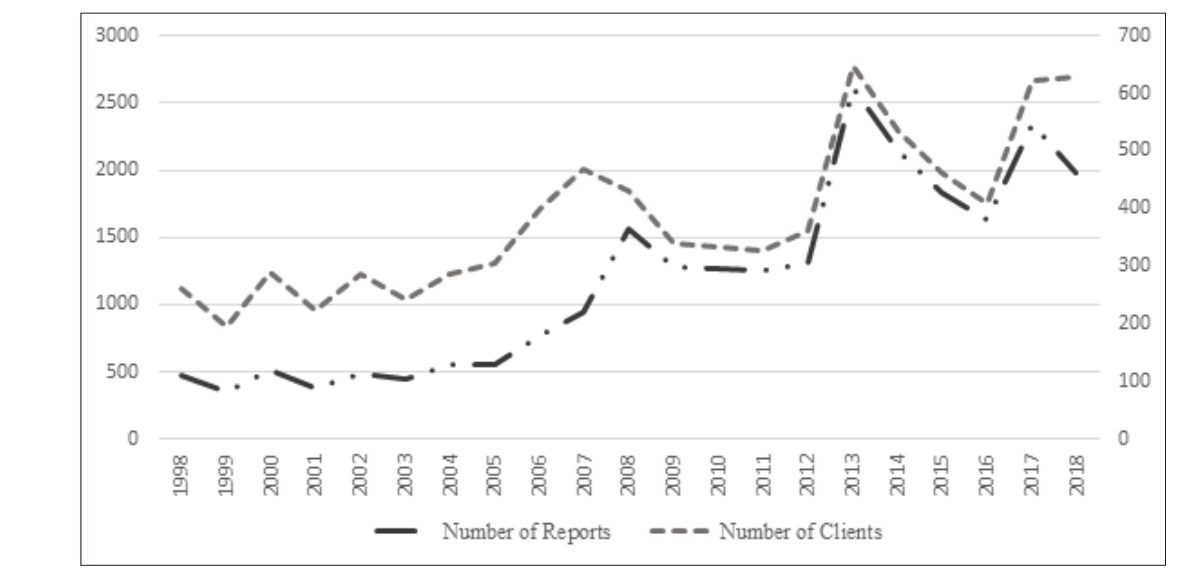

Source: Center for Responsive Politics (2019)

The largest number of lobbying reports on immigration were predominantly filed by high-tech companies and national labor union associations seeking more favorable immigration policies. The top corporate clients of lobbying firms with the most reports filed since 2003 included Microsoft, with 429 reports, Oracle, with 172 reports, and Intel and Qualcomm, with approximately 140 reports each. National labor unions included the AFL-CIO, the National Association of Home Builders, the National Concrete Masonry Association and the National Association of Software \& Services. (Center for Responsive Politics 2019) Mainly these groups were looking for policy reforms to boost the number of temporary workers on $\mathrm{H} 1 \mathrm{~B}$ and $\mathrm{H} 2 \mathrm{~B}$ visas, thereby enhancing the pathway to temporary or permanent legal residency or citizenship. (The Congress 2009; AFL-CIO 2019) Although associations, such as the homebuilders' lobby noted above, included in their filings specific policy targets, such as the implementation of the E-Verify system to deter employers from hiring undocumented immigrants, both industrial interest groups and labor unions predominantly filed lobbying reports petitioning for a pro-immigrant policy agenda.

As the technology industry relies heavily on immigrant labor, which in most cases 
is permitted through the $\mathrm{H} 1 \mathrm{~B}$ visa program ${ }^{2}$, the current allocation of $\mathrm{H} 1 \mathrm{~B}$ visas is concentrated in the top technology companies, including Microsoft, Apple, Google, and Amazon. (Donnelly, 2018) Microsoft alone employs more than 5,00o people through this visa program, and other tech giants, such as Amazon and Expedia, employ thousands of H1-B visa holders. (United States District Court Washington 2017) Microsoft serves as a prime example of a leading high-tech company that has lobbied consistently for an expansionary immigration agenda. The corporation has filed more than 400 reports since the Lobbying Disclosure Act took effect in 1995 and has filed, an annual average of 42 lobbying statements per year from 1995 until 2015. Tracing Microsoft's trajectory on immigration policy lobbying helps us examine whether the high-tech industry has become less inclined to support proimmigration policies in recent years.

Figure 2. Microsoft's annual number of lobbying reports on immigration and annual lobbying expenditures (in millions of dollars)

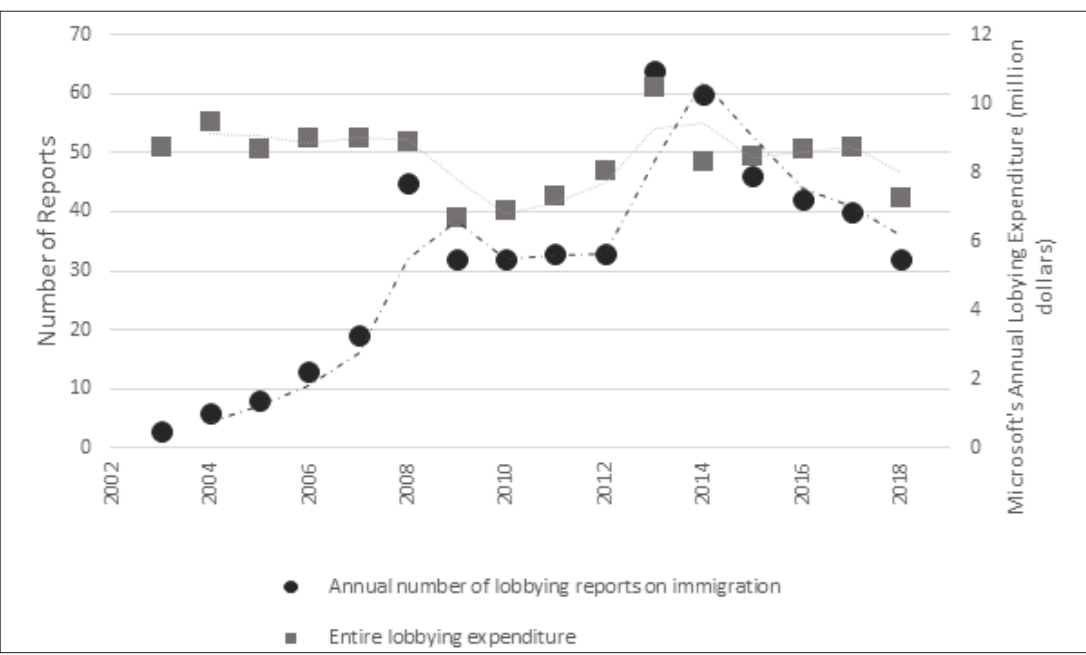

Source: Center for Responsive Politics (2019)

2 The $\mathrm{H} 1 \mathrm{~B}$ visa is a temporary visa issued to high-skilled immigrant workers which first came about in legislation in 1952 through the Immigration and Nationality Act. The size of the H1B visa cap was expanded dramatically during President George H.W. Bush office, from 65,000 to 115,000. However, the H1B Visa Reform Act of 2004 rolled back the number to 65,000 visas per year, with 20,000 visas extra under the J1 status which requires a master's degree or equivalent. The visa cap has remained unchanged since 2004 despite the increasing demand for skilled labor in technology and STEM industries. 
As shown in Figure 2 above, the number of reports filed by Microsoft has increased from fewer than five reports filed each year prior to 2003 to closer to 10 reports per year since 2008. Immigration also remained as one of the top three most frequently lobbied policy areas for Microsoft from 2006 to 2018, along with other issues such as taxes, telecommunications, computers, and information technology. (Center for Responsive Politics 2019) Although the number of immigration lobbying reports gradually decreased from 2013 to 2018, the general upward trend from 2008 to 2013 and the downward trend from 2013 to 2018 correlate with Microsoft's overall lobbying expenditures from year to year. Nevertheless, Microsoft spent 24 percent of its funds for lobbying on issues concerning immigration, underscoring the corporation's sustained priority of influencing immigration policies.

Yet it is not only consistency in immigration-related lobbying activities that speak to the willingness of key interest groups to pursue a pro-immigration agenda. The specific policy targets of interest groups have also changed and evolved over time, showing which specific areas of immigration policy interest groups are concerned with. Most commonly, high-tech companies aim to ease constraints on skilled immigration through the $\mathrm{H} 1 \mathrm{~B}$ and J1 visas. Prominent technology corporations such as Microsoft, Alphabet, and Amazon have lobbied for bills relating to the increase of the $\mathrm{H} 1 \mathrm{~B}$ visa cap and providing a path to citizenship for undocumented immigrants. 2015 (United States Senate 2018) In 2008, Microsoft filed more than 20 reports in favor of the Comprehensive Immigration Reform Act of 2007, which died in the U.S. Senate, and in 2016, it filed several reports in favor of the unsuccessful Immigration Innovation Act of 2015 which aimed to increase the number of immigrants allowed per year under the H1B visa cap to levels between 115,000 and 195,000 per year depending upon market conditions. (United States Senate 2008; 2016) (The current H1B cap is 65,000 per year.)

The general trend in immigration politics has moved toward lowering barriers for high-skilled immigrants and increasing the number of admitted skilled workers, albeit through temporary stays via $\mathrm{H} 1 \mathrm{~B}$ and $\mathrm{J} 1$ visas. Recently, however, high-tech companies began to lobby for different legislation - framed in public debate as the Dream Act - concerning undocumented immigrants who had entered the United States (with their parents) as children. After the Dream Act failed to pass Congress over a period of several years, then-President Barack Obama issued an executive order to launch the Deferred Action for Childhood Arrivals (DACA) provisions that spare many of these young people - now young adults - from immediate deportation and places them on track toward work permits. Following President Trump's announcement in 2017 that 
DACA would be withdrawn, companies such as Microsoft, Amazon, Accenture, Facebook, eBay and Alphabet (the parent company of Google) filed a number of lobbying reports in support of the program (United States Senate 2018; 2019), which currently remains in place amid ongoing legal challenges. (United States Senate 2018) Brad Smith, the president of Microsoft, in this regard, stated that "a lasting solution for the country's Dreamers is both an economic imperative and a humanitarian necessity."(Smith 2019) It is interesting that Alphabet and Microsoft are now rallying to save DACA considering that neither of the two companies lobbied for the former Dream Act; both companies are now concerned about how Trump's immigration politics threaten their employees. (United States Senate 2018)

Figure 3. How Microsoft allocates its lobbying expenditures on immigration

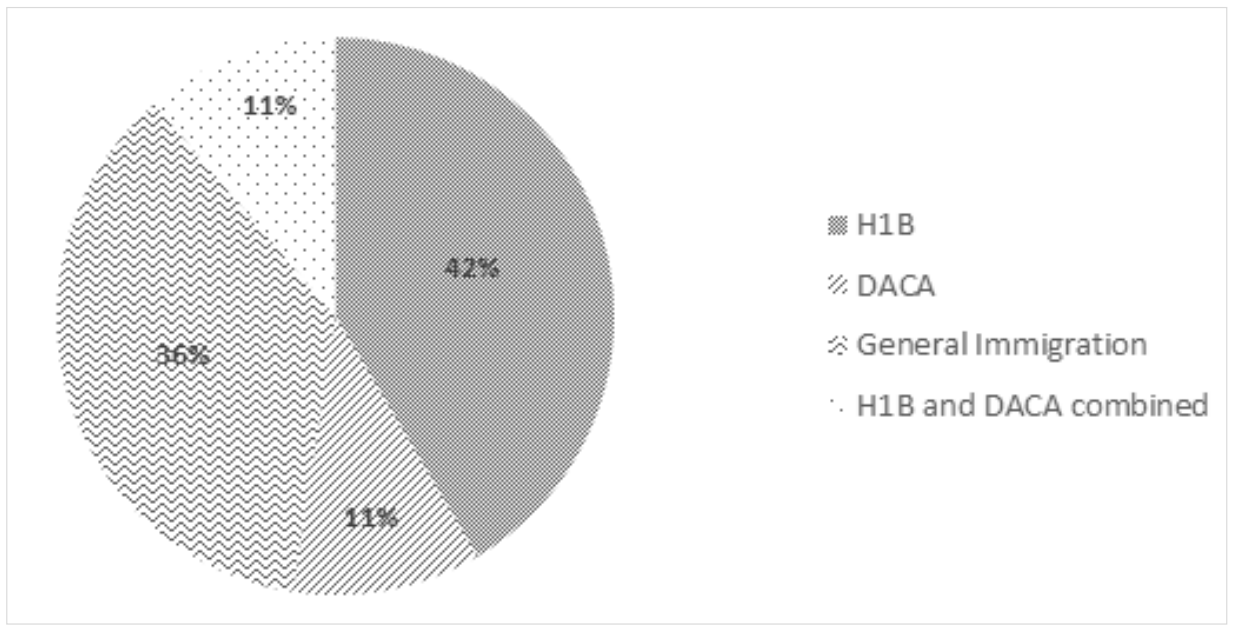

Source: Center for Responsive Politics (2019)

Microsoft in 2018 spent more than 20 percent of its immigration-related lobbying expenses on DACA. Although expanding or enhancing the DREAM Act, which concerns undocumented youth and young adults, is a far more widely encompassing agenda item than the company's specific interests, clearly Microsoft decided that protecting its employees from losing a pathway to citizenship or, worse, possible deportation had become important objectives well worth fighting for in the Trump era. On a similar note, Alphabet lobbied comprehensively on travel restrictions recently introduced by the Trump administration, as this threatened to curtail some of its employees' rights to travel in and out of the United States. 
On the other hand, several national labor unions representative of immigrant dependent businesses, such as the construction industry, agribusiness, and high-tech industry, also lobbied heavily on the issue of immigration. Unlike the corporate interest groups, labor unions' lobbying targets were dispersed across both expansionary policies to invite more seasonal workers and restrictive policies to curtail the employment of undocumented immigrants. Specific policy targets included the increase in allocation and general relaxation of the H2B visa (temporary working visa for nonagricultural services) and the $\mathrm{H1B}$ visa, as well as the enforcement of the E-Verify system. (United States Senate 2018) For a large part of America's labor union history, union members have been wary of admitting immigrant workers, worrying that the influx of foreign workers will diminish the leveraging power of the members. Political Action Committees (PACs) contribution from agribusiness and construction industries have also been largely favorable of the Republican party, despite their heavy reliance on seasonal and temporary immigrant workers. (Center for Responsive Politics 2018)

In essence, although certain immigrant dependent industries inherently support the right-wing party due to other grounding economic and political reasons, the issue of immigration tends to cut across partisan divides and allows these businesses to lobby for expansionary immigration policies when it concerns the supply of foreign workers. Such cross-ideological tendencies have been described as the "strange bedfellow" coalition, a collective effort from agribusiness, high-tech business and ethnic advocacy groups $d$ to initiate a "grand bargain" in immigration. (Zolberg 2006) In many cases, these seemingly unrelated interest groups will work across sectors and ideologies to push for a large-scale immigration reform that allows the expansion of temporary visas for STEM and seasonal agriculture and businesses.

The strange bedfellow theory, however, disregards labor unions as a possible coalition member, given their distinct constituency to retain the workers' leverage and guard against the deletion of job opportunities caused by immigrant workers. (Williamson 2005) Over the last decade, however, labor unions of immigrant dependent businesses have been tilting towards a moderately pro-immigrant position, focusing on the expansion of $\mathrm{H} 2 \mathrm{~B}$ visa cap and also occasionally lobbying for the enhancement of immigrant welfare. (United States Senate 2018). The labor unions' increasing efforts to influence immigration policies is demonstrated through the rising numbers of immigration lobbying reports filed from the three major labor unions: AFLCIO, the National Association of Home Builders, and the National Association of Software \& Services. 
Figure 4. Annual number of lobbying reports on immigration filed from AFL-CIO, the National Association of Home Builders, and the National Association of Software \& Services.

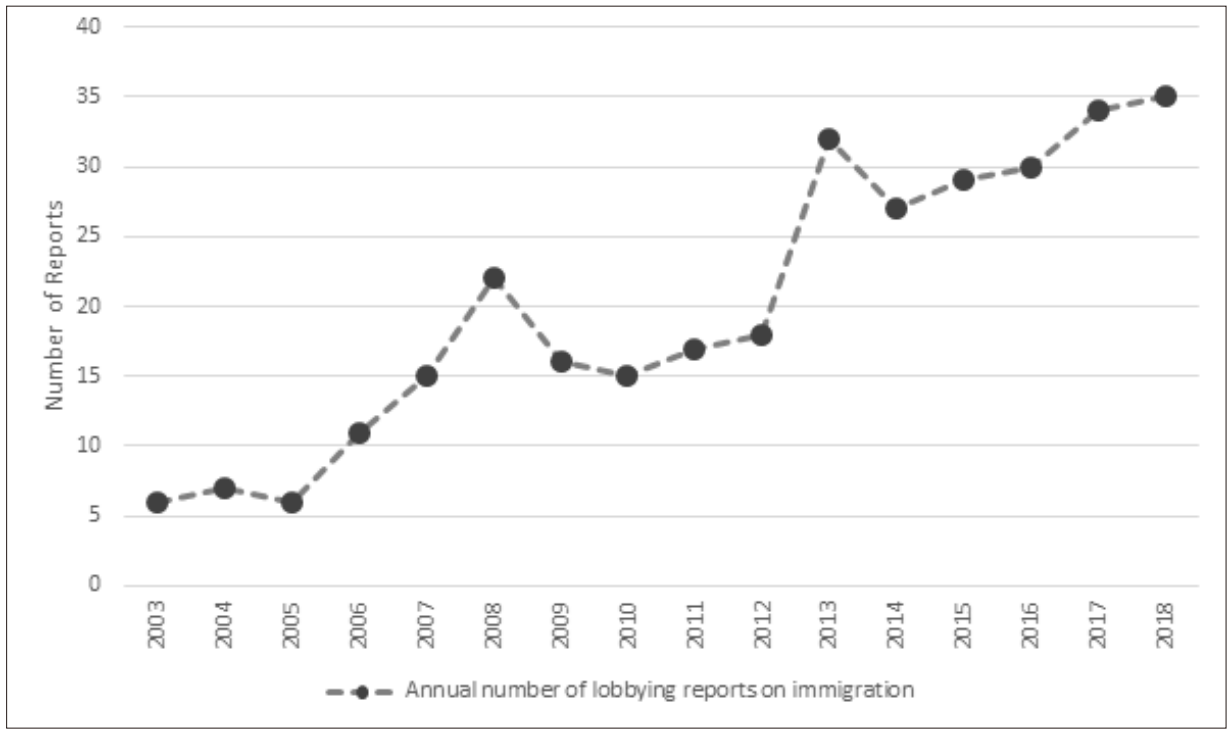

Source: Center for Responsive Politics (2019)

As shown in Figure 4, the combined number of lobbying reports filed from the three labor unions consistently increased over the past decade, showing a steep rise from the years 2008 to 2018. For both the National Association of Home Builders and the National Association of Software \& Services, immigration remained their top lobbying priority for several years since 2010, alongside retirement, trade, and taxes. (Center for Responsive Politics 2019) The diversification of lobbying targets within the realm of immigration, from solely focusing on maximizing the number of temporary workers in the early 2000s to supporting the Dream Act in 2019, also demonstrates the labor union's willingness to not only invite more immigrants but also to protect their lawful rights. A statement from the homebuilder's association chairman Granger MacDonald, in response to the Trump administration's decision to wind down the Deferred Action for Childhood Arrivals (DACA) program, illustrates in a nutshell the labor unions' mixed position on immigration policies: prioritizing a market-based approach to labor immigration while supporting select policies which protect immigrant rights. The chairman asserts that the need to find

"a permanent legislative solution to protect the 'Dreamers' underscores the 
urgent need for lawmakers to pass comprehensive immigration reform ... NAHB believes that any comprehensive reform should protect our nation's borders; include a new, market-based visa program that would fill labor gaps to ensure that the nation has a workforce that is sufficient to meet its housing construction and restoration needs; and provide a workable employment verification system." (MacDonald 2017)

Drawing from the labor unions' growing efforts to expand the temporary visa cap and its inclination to protect the young and vulnerable immigrant population, it is clear that the unions are not at stark odds with the corporate interest groups, unlike their conventional anti-immigrant reputation. Although most lobbying reports from these unions still include provisions for restrictive policies such as the E-Verify system and border control, the overall lobbying efforts have been focused on expansionary immigration policies rather than restrictive. Many labor unions representing the immigrant dependent industries now lobby strongly for policies that can alleviate the sector's labor shortage and revitalize the industry rather than barring the entry of foreign workers or deporting youth immigrants.

In sum, the key corporate and union interest groups share a similar lobbying agenda in that they both prioritize the increase of visa allocations for either skilled or temporary laborers and also lobby for specific pro-immigrant policies that concern the wellbeing of their employees.

Table 1. List of interest groups and their target policy for lobbying

\begin{tabular}{cccc}
\hline \multirow{2}{*}{$\begin{array}{c}\text { Lobbying } \\
\text { Company/Association }\end{array}$} & H1B/H2B & DACA & Travel restriction \\
\cline { 2 - 4 } Microsoft & $\mathrm{O}$ & $\mathrm{O}$ & $\mathrm{X}$ \\
Alphabet (Google) & $\mathrm{O}$ & $\mathrm{O}$ & $\mathrm{O}$ \\
Amazon & $\mathrm{O}$ & $\mathrm{O}$ & $\mathrm{X}$ \\
Facebook & $\mathrm{O}$ & $\mathrm{O}$ & $\mathrm{X}$ \\
AFL-CIO & $\mathrm{O}$ & $\mathrm{X}$ & $\mathrm{X}$ \\
National Association of Home & $\mathrm{O}$ & $\mathrm{X}$ & $\mathrm{X}$ \\
Builders & & &
\end{tabular}

Source: Center for Responsive Politics (2019)

As shown in Table 1, the lobbying efforts of large technology companies and labor unions on various pro-immigration policy agenda, moving away from only lobbying for $\mathrm{H} 1 \mathrm{~B}$ and $\mathrm{H} 2 \mathrm{~B}$ visa allocations, signify that interest groups today 
regard immigration policy not only as a labor market issue but also as matters of safety and well-being for their current employees. Having integrated immigrant workers into the industry as a crucial part of their respective workforces, interest groups now face the possibility of new immigration policies that could place their employees in jeopardy. As a result, many companies and unions have stepped up their lobbying efforts, pushing for more diverse and ambitious policy targets. Given the seemingly constant need to augment skilled and temporary labor, businesses and labor unions are now calling for comprehensive, pro-immigration policy reforms and lobbying against the restrictive policies introduced by the Trump administration such as the rollback of DACA.

\section{THE GENERAL PUBLIC SUPPORTS IMMIGRATION MORE STRONGLY THAN BEFORE}

Given that interest groups overall have maintained a steady drumbeat of lobbying in support of immigration, could the general public be driving the shift toward more restrictive measures? In this section, we show that this is not the case with the general public, in the aggregate, although voluble segments of American public opinion are virulently against immigration and have created an opening for President Donald Trump.

Previous studies on American public opinion on immigration has focused mainly on American public sentiment towards immigrants, in the face of adversities such as job insecurity, cutbacks in welfare, and public resources, perceptions (often inaccurate) of increasing crime rates and changes in the ethnic and cultural characteristics of local populations. (Sobczak 2010) The prevailing narrative has cast the public mainly as cautious at best with regard to immigration and put forward the notion of a disconnect between what the public wants and what interest groups and pro-immigration elites have been advocating. (Joppke 1998; Freeman 1995) This perspective of a disconnect between the wishes of the general public and the positions of interest groups also casts the public's leverage as weak when it comes to influencing government and shaping public policy, and that pro-immigrant elites and interest groups will eventually succeed in outmaneuvering public opinion and bending policies to suit their particular interests regardless of any possible public backlash. (Freeman 1995) This disconnect thesis between mass opinion and immigration policy has served as an example of how the views of the general public are often sidelined by decision-makers, leading to descriptions of immigration policymaking as largely oligarchic. (Schuck 2007)

Recently, however, studies have found that public sentiment varies depending on specific categories of immigration, with the public more supportive, on 
balance, of relatives of family members already in the United States, high-skilled workers, and refugees (Levy et al. 2016, 664) This evidence, therefore, weakens the disconnect theory by demonstrating that the public is not always negatively disposed to immigration. Moreover, recent polling results have shown a shift in public opinion, closing the long-held gap between the number of Americans preferring to decrease the number of immigrants and those who want to increase the number of immigrants. Along with Levy, Wright and Citrin's experimental findings, which revealed that the public's preferences on immigration are more favorable when different segments of immigration - family reunification, highskilled labor, and refugees - are considered, recent polling results underline a strong pro-immigration sentiment from the public. As illustrated below in Figure 5, when respondents were asked, "Should immigration be kept at its present level, increased or decreased?" - the standard immigration preference question used by Gallup, the General Social Survey and the American National Election Studies - the American public in 2005 preferred by a ratio of three to one to decrease the level of immigration rather than to increase immigration (46 percent and 16 percent respectively).

Five years later, in 2010, amid the fallout of the 2008 economic crisis, the public still preferred to reduce the level of immigration by a ratio of more than two to one (42 percent and 18 percent respectively). This gap began to close in 2012 and move toward a ratio of one to one, eventually balancing out in 2018 to 28 percent of the public preferring to increase immigration levels and 29 percent preferring the opposite. Considering that the percentage of respondents that would just as soon hold constant immigration levels remained basically unchanged over the years, the recent upward trend in the ratio of people in favor of an increase is striking. The percentage of Americans looking for a decline in immigration has fallen by half since 2012, and more and more Americans throughout the past decade have shifted toward a pro-immigration position, preferring an increase in the number of immigrants rather than the status quo. 
Figure 5. American general public opinion on whether to increase, decrease or hold constant immigration levels.

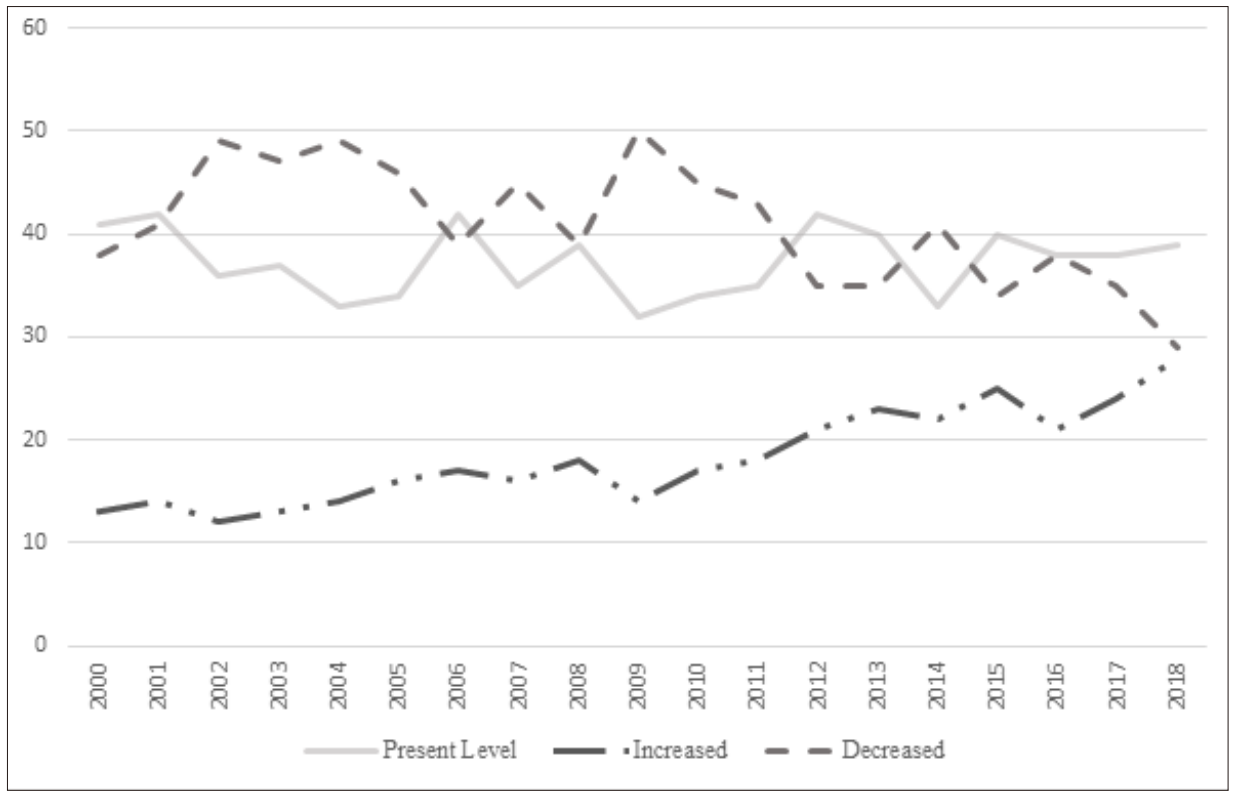

Source: Gallup (2019)

A similar shift in public opinion in favor of immigration has emerged in results from the International Social Survey Program (ISSP). When asked - "On the whole, do you think immigration is a good thing or a bad thing for this country today?" - 75 percent of the respondents answered favorably while only 19 percent answered negatively.

In summary, the overall balance of public opinion in the United States as of 2018 views immigration favorably, with segments evenly split on the question of whether to increase or decrease the current level of immigration. Notably, in light of all the media attention that frames immigration in negative terms, the number of Americans who prefer to decrease the level of immigration has dropped sharply in recent years while the percentage of Americans supporting an increase in immigration has risen in the same time period. Furthermore, in 2017, exactly 50 percent of the American public thinks immigration does not negatively affect their job opportunities, although less favorably, the same percentage worries that immigration might result in higher crime rates. (Gallup 2019) The shift toward more positive public sentiment on immigration weakens the longstanding 'disconnect' theory that policy outcomes on immigration reveal 
a gap between a restrictive, even hostile public toward immigrants and powerful pro-immigrant interest groups overriding negative public opinion to push expansionary immigration policies through Congress. Now, the gap is widening between a largely (yet perhaps mildly) supportive public and highly restrictive, anti-immigrant policies which only seems earns support from a minor section of the public. (Cohn 2019; Wilkinson 2018)

\section{POLARIZED PUBLIC OPINION AND POLITICAL OPPORTUNITY FOR DONALD TRUMP}

As general public opinion and interest group lobbying have slowly but surely converged into a clear pro-immigration position, it is questionable as to why Trump would enforce a series of anti-immigration policies that only seem to represent and generate support from a minority of voters in the United States. What kinds of political benefits can the president win through pursuing hardline immigration policies despite going against public opinion (in the aggregate) as well as the overall balance of interest group pressure? Does gaining allegiance from minority segments of the public provide a better political opportunity for Trump than representing the majority? To examine how anti-immigration policies and restrictive views on immigration have paved the way for a political opportunity for Trump, we analyzed the polarization in American politics and the accompanying segmentation in public opinion in relation to the 2016 United States presidential election results.

Elements of public dissatisfaction with pre-existing immigration policies and promises to impose new barriers and restrictions became rhetorical cornerstones of Trump's election campaign. In a September 2016 campaign speech in Arizona, Trump claimed that the United States immigration system "serves the needs of wealthy donors, political activists, and powerful, powerful politicians... (but) does not serve you, the American people." (The New York Times 2016) Framing unauthorized immigration as especially threatening to national security and urgently requiring greater control caught the public's attention throughout the 2016 presidential campaign. Immigration ranked as one of the top concerns for American voters in 2016, along with other issues such as the economy and terrorism. In a Pew Research Center survey, approximately 70 percent of registered voters nationwide chose immigration as a "very important" issue while in the previous presidential election, a comparatively low 42 percent thought the 
same. ${ }^{3}$ (Pew Research Center 2012; 2016) Immigration took center stage as a leading issue for Trump's campaign and his supporters, with nearly 80 percent of Trump supporters viewing immigration as a matter of great importance.

When we compared each state's view on immigration in 2015 and how the statewide presidential election results turned out in 2016, a plausible correlation emerged between public sentiment on immigration and candidate choices. As shown in Figure 6, all states that voted Republican, except for Texas and Arizona, had a negative position on immigration. More than half the survey respondents in these states considered immigrants as threatening toward American culture and values. (Cooper et al. 2016) Although some small and rural states in which the public holds rather guarded views on immigrants - including the northern New England trio of Maine, New Hampshire, and Vermont had voted for Democratic nominee Hillary Clinton, most states exhibited an association between candidate choice and immigration sentiment. States with relatively positive views on immigration generally chose Clinton, while states with relatively negative views on immigrants chose Trump.

3 In 2012, immigration was one of the least concerned issues for the election where it ranked $15^{\text {th }}$ out of 18 voting issues, followed by abortion and gay marriage. In 2016, however, immigration was pushed up to the $7^{\text {th }}$ most concerned issue while abortion and LGBT issue still remained on the bottom of the list. 
Figure 6. 2016 U.S. presidential election results and the percentage of voters who believe that a growing number of immigrants strengthens American society.

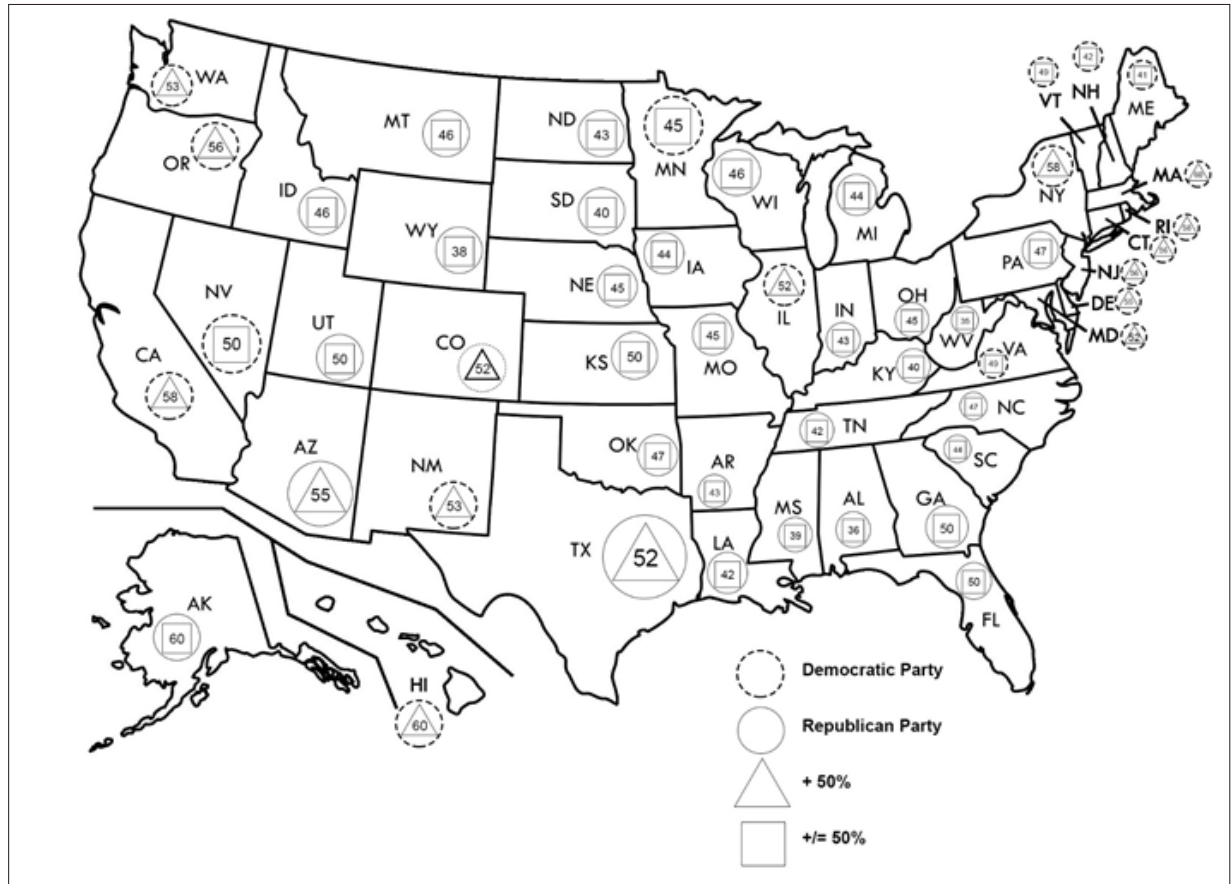

Source: PRRI American Values Atlas (2015); BBC News (2016)

*The PRRI survey was not conducted in the District of Columbia.

If one were to divide the states into two categories (1) states with more than 50 percent of respondents who say immigrants strengthen American society (2) states with no more than 50 percent of respondents who say immigrants strengthen American society, then the first pro-immigration group of states totals 259 electoral votes, while the second, anti-immigration group of states totals 247 votes. In this regard, targeting pro-immigration states seems to yield a higher number of electoral votes, rather than Trump's strategy (both as a candidate and as the current president) that targets, in effect, relatively antiimmigration states. However, since traditionally Republican states like Texas and Arizona, with 49 electorate votes between them, landed in the first group, then targeting anti-immigrant states plus Texas and Arizona could provide a roadmap to victory.

Furthermore, regarding the swing states that are widely seen as holding the keys to the presidential election, seven out of 11 of these states were won by 
Trump, and six of these seven Trump-electing states had, on balance, negative public opinion on immigration. With the exception of Pennsylvania, the remaining six swing states that voted for Trump - Florida, Iowa, Michigan, North Carolina, Ohio, and Wisconsin - fell within the anti-immigration category. Even when factoring out Pennsylvania, appealing to the anti-immigrant swing states still would have garnered more electoral votes (a total of 94 electoral votes for the six anti-immigrant swing states - compared with 42 electoral votes from the five pro-immigrant swing states) - than appealing to the pro-immigrant swing states. The bottom line is that although the dominant sentiment on immigration within general public opinion in the United States was more positive than negative in $2015^{4}$, the polarization across the country on this issue created an opening for Trump's victory by targeting anti-immigrant swing states and also securing traditionally Republican states with nativist rhetoric.

Trump's victory in 2016, however, did not represent the majority opinion in the United States on immigration, and President Trump actually remains distant from the mainstream public sentiment in 2018. In addition to general public opinion polling indicating support for immigration, low public support for Trump's border wall initiative seems to indicate that the president is pushing policies that are popular only among minority segments. (Cohn 2019) According to a survey conducted by cable television network Fox News following the 2018 midterm elections, only 13 states had majority support for Trump's border wall, and these were states in which the citizens were predominantly negative on immigration, while the balance of public opinion in 26 states (totaling nearly 400 electoral votes) opposed the border wall. Two of the largest swing states, Pennsylvania and Michigan - where many citizens voted for Trump because of economic issues rather than immigration -- were also unfavorable towards the building of the wall, despite their support for Trump in 2016. The marginal support for the wall along with frustration over the recent government shutdown suggests that Trump's aggressive measures to stop the 'immigration crisis' are not attracting support from the majority of Americans. Although the president succeeded in strategically capturing just enough electoral votes in 2016 from segments of the public displaying negative views towards immigration, it is hardly certain that the same strategy will guarantee Trump re-election in 2020. Closer alignment with general public opinion as well as bargaining with related interest groups will be necessary for any candidate to win the office.

450 percent of the national respondents had a pro-immigration position and only 34 percent had an anti-immigration position 


\section{CONCLUSION}

The growing number of pro-immigrant Americans and the sustained efforts from interest groups to curb bars on immigration have closed the long-held gap between the formerly incongruent entities of public opinion, and interest groups. Against the popular notion that pro-immigration interest groups simply override the public's restrictive sentiments in terms of passing expansionary immigration policies, our findings suggest that the public is now largely convergent with interest groups in favoring immigration. The public now exhibits more acceptance towards specific segments of immigration including family reunification and skilled labor as well as the overall incoming of immigrants in general. In this regard, President Trump's extensive anti-immigration policies are at odds with the popular consensus between the general public and interest groups, although he insists in his speeches, tweet, and rallies that he is carrying out the wishes of the American people. With the shrinking anti-immigration sentiment and consistent corporate and labor union lobbying on expansionary immigration policies, any winning presidential candidate in 2020 might well manage to build an assemblage of electoral votes from states holding moderate to strong pro-immigration perspectives than to maneuver through select antiimmigration states.

\section{REFERENCES}

AFL-CIO. "Immigration". Accessed at https://aflcio.org/issues/immigration (March 3, 2019).

Alvarez, Priscilla, and Tammy Kupperman. 2019. "Exclusive: White House preparing draft national emergency order, has identified $\$ 7$ billion for wall." CNN (January 24).

Bureau of Labor Statistics. 2018. "FOREIGN-BORN WORKERS: LABOR FORCE CHARACTERISTICS - 2018”Accessed at https://www.bls. gov/news.release/pdf/forbrn.pdf. (March 1, 2019).

Burns, Peter, and James G Gimpel. 2000. "Economic Insecurity, Prejudicial Stereotypes, and Public Opinion on Immigration Policy." Political Science Quarterly 115(2), 201-225.

CBP Border Security Report. 2017. "U.S. Customs and Border Protection". Accessed at https://www.cbp.gov/sites/default/files/assets/ documents/2017-Dec/cbp-border-security-report-fy2017.pdf.(March 3, 2019). 
Center for Responsive Politics. Accessed at https://www.opensecrets.org/. (January 5, 2019).

. "Agribusiness: Long-Term Contribution Trends". Accessed at https:// www.opensecrets.org/industries/totals.php?ind=A. (August 4, 2019).

. "Construction: Long-Term Contribution Trends". Accessed at https:// www.opensecrets.org/industries/totals.php?ind=C. (August 4, 2019).

. "Immigration Issue Profile". Accessed at https://www.opensecrets. org/lobby/issuesum.php?id=IMM. (March 1, 2019)

. "National Assn of Home Builders". Accessed at https:// www.opensecrets.org/lobby/clientissues_s pec. php?id=Dooooooo86\&year=2019\&spec $=$ IMM. (August 4, 2019).

Chavez, Leo R. 2008. The Latino Threat: Constructing Immigrants, Citizens, and the Nation. Stanford, CA: Stanford University Press.

Citrin, Jack, and John Sides. 2008. "Immigration and the Imagined Community in Europe and the United States." Political Studies 56(1), 33-56.

Cohn, Nate. 2019. "The Wall Is Not Popular. (And Neither Is Trump.)". The New York Times (January 12).

The Congress. 2009. "Comprehensive Reform of Immigration Laws". Accessed at https://www.congress.gov/bill/111th-congress/house-bill/4321/text (February 1, 2019).

Cooper, Betsy, Daniel Cox, Rachel Lienesch, and Robert P Jones. 2016. PRRI. March 29. Accessed at https://www.prri.org/wp-content/ uploads/2016/03/CHART-5-1.jpg.(March 1, 2019).

Council on Foreign Relations. "U.S. Postwar Immigration Policy". Accessed at https://www.cfr.org/timeline/us-postwar-immigration-policy. (March 3, 2019).

Donnelly, Grace. 2018. "37\% Of H-1B Visa Holders Work At These 20 Companies”. The Fortune (August 3).

Facchini, Giovanni, Anna Maria Mayda, and Prachi Mishra. 2011. "Do interest groups affect US immigration policy?” Journal of International Economics 85(1), 114-128.

Freeman, Gary P. 1995. "Modes of Immigration Politics in Liberal Democratic States." The International Migration Review 29(4), 881-902.

Gallup. 2019. "Immigration.” Accessed at https://news.gallup.com/poll/166o/ immigration.aspx. (March 5, 2019).

Hainmueller, Jens, and Daniel J Hopkins. 2014. "Public Attitudes Toward Immigration.” Annual Review of Political Science 17, 225-249.

Hainmueller, Jens, and Michael J Hiscox. 2010. "Attitudes toward Highly 
Skilled and Low-skilled Immigration: Evidence from a Survey Experiment-Erratum." American Political Science Review 104(3), 6184.

Hanson, Gordon H., and Antonio Spilimbergo. 2001. "Political economy, sectoral shocks, and border enforcement." Canadian Journal of Economics 34(3), 612-638.

Happel, Ellie. 2018. "Ending TPS for Haitians was unlawful - and racist, too". Miami Herald (August 22).

Holland, Steve, and Jeff Mason. 2019. "Trump wounded by border wall retreat in deal to end shutdown". Reuters (January 26).

Holsti, Ole. 2004. Public Opinion and American Foreign Policy, Revised Edition. Ann Arbor, MI: University of Michigan Press.

Jaret, Charles. 1999. "Troubled by Newcomers: Antiimmigrant Attitudes and Action during Two Eras of Mass Immigration to the United States." Journal of American Ethnic History 18(3), 9-39.

Joppke, Christian. 1998. "Why Liberal States Accept Unwanted Immigration." World Politics 50(2), 266-293.

Levy, Morris, Matthew Wright, and Jack Citrin. 2016. "Mass Opinion and Immigration Policy in the United States: Re-Assessing Clientelist and Elitist Perspectives." Perspectives on Politics 14(3), 660-680.

Microsoft. 2018. "Statement from Microsoft President Brad Smith on DACA lawsuit ruling." Accessed at https://blogs.microsoft.com/on-theissues/2018/04/24/statement-from-microsoft-president-brad-smithon-daca-lawsuit-ruling/. (March 4, 2019).

Merolla, Jennifer, Karthick Ramkrishnan, and Chris Haynes. 2013. "Illegal,' 'Undocumented,' Or 'Unauthorized': Equivalency Frames, Issue Frames, and Public Opinion on Immigration." Perspectives on Politics 11(3), 789-807.

National Association of Home Builders. 2017. "Statement from NAHB Chairman Granger MacDonald on Immigration Reform." Accessed at http://www.nahb.org/news-and-publications/press-releases/2017/09/ statement-from-nahb-chairman-granger-macdonald-on-immigrationreform.aspx. (August 4, 2019).

Newman, Benjamin J, Christopher D Johnston, April A Strickland, and Jack Citrin. 2012. "Immigration Crackdown in the American Workplace: Explaining Variation in E-VerifyPolicy Adoption Across the U.S. States." State Politics \& Policy Quarterly 12 (2), 160-182.

Pew Research Center. 2012. "Issues of the 2012 Campaign". Accessed at http://www.people-press.org/2012/04/17/section-2-issues-of-the- 
2012-campaign/. (March 10, 2019).

. 2016. "Top voting issues in 2016 election". Accessed at http://www. people-press.org/2016/o7/o7/4-top-voting-issues-in-2016-election/. (March 3, 2019).

Sands, Geneva. 2018. “81 children separated at border since Trump’s executive order on dividing families". CNN (December 6).

Schuck, Peter. 2007. The Disconnect Between Public Attitudes and Public Policy on Immigration. Edited by Carol Swain. New York, NY: Cambridge University Press.

Sobczak, Michael. 2010. American Attitudes Toward Immigrants and Immigration Policy. El Paso, TX: LFB Scholarly Pub. LCC.

State of Washington. 2017. "Plaintiff, v. Donald TRUMP, in..., 2017 WL 443297 (2017)”. Accessed at https://www.us-recht.jura.uni-koeln.de/sites/ usrecht/Unterlagen_Materialien/SS_19_Unterlagen/Constitutional_ Law/washington_v._trump_Complaint_for_Declaratory_and_ Injunctive_Relief.pdf (March 4, 2018).

The New York Times. 2016. “Transcript of Donald Trump's Immigration Speech.” (September 1)

Tichenor, Daniel. 2002. Dividing Lines: The Politics of Immigration Control in America. Princeton, NJ: Princeton University Press.

United States House of Representatives. "Lobbying Disclosure". Accessed at https://lobbyingdisclosure.house.gov. (March 10, 2019).

United States Senate. 2008. "Lobbying Report”. Accessed at https://soprweb. senate.gov/index.cfm? event $=$ getFilingDetails\&filingID $=0630 \mathrm{~F} 427$ EA45-4C47-A6CD-8Co085A7C380\&filingTypeID=60. (March 3, 2019). . 2016. "Lobbying Report". Accessed at https://soprweb.senate.gov/ index.cfm?event $=$ getFilingDetails\&filingID $=0458557 \mathrm{~F}-0257-4 \mathrm{DE} 5-$ B57E-B12EECABE487\&filingTypeID=69. (March 5, 2019).

. 2018. "Lobbying Report". Accessed at https://soprweb.senate.gov/ index.cfm?event=getFilingDetails\&filingID=62812503-8673-4E4BBB6E-4EB73D28EECC\&filingTypeID=69. (December 28, 2018). . 2018. "Lobbying Report". Accessed at https://soprweb.senate.gov/ index.cfm?event $=$ getFilingDetails\&filing $\mathrm{ID}=1 \mathrm{C} 75451 \mathrm{E}-\mathrm{BE} 48-4 \mathrm{D} 35$ AA6A-FE47CC47Eo6C\&filingTypeID=69. (March 6, 2019). . 2018. "Lobbying Report". Accessed athttps://soprweb.senate.gov/ index.cfm?event=getFilingDetails\&filingID=62812503-8673-4E4BBB6E-4EB73D28EECC\&filingTypeID=69. (March 6, 2019).

. 2018. "Lobbying Report". Accessed at https://soprweb.senate.gov/ index.cfm? event=getFilingDetails\&filingID=094ABE1F-FFEF-4AA5- 
8971-721D6D672164\&filingTypeID=60. (March 2, 2019). . 2018. "Lobbying Report". Accessed at athttps://soprweb.senate.gov/ index.cfm? event $=$ getFilingDetails\&filing $\mathrm{ID}=1 \mathrm{C} 75451 \mathrm{E}-\mathrm{BE} 48-4 \mathrm{D} 35^{-}$ AA6A-FE47CC47Eo6C\&filingTypeID=69. (March 2, 2019). . 2018. "Lobbying Report". Accessed at https://soprweb.senate.gov/ index.cfm? event=getFilingDetails\&filingID=4A1D97B7-7149-4ECD913B-3A6B9F8FBA43\&filingTypeID=60. (March 2, 2019).

. 2018. "Lobbying Report". Accessed at https://soprweb.senate.gov/ index.cfm? event $=$ getFiling Details\&filingID $=017626 \mathrm{DC}-\mathrm{F} 8 \mathrm{E} 3-4 \mathrm{~F} 11-$ BC7F-556B3329318D\&filingTypeID=69. (March 4, 2019). . 2018. "Lobbying Report". Accessed at https://soprweb.senate.gov/ index.cfm? event=getFilingDetails\&filingID=9ACBDD95-9991-428EAB81-699018B58178\&filingTypeID $=51$. (August 4, 2019). . 2018. "Lobbying Report". Accessed at https://soprweb.senate.gov/ index.cfm? event $=$ getFilingDetails\&filing $\mathrm{ID}=5 \mathrm{~B} 785 \mathrm{E} 8 \mathrm{~B}-\mathrm{BoB} 2-489 \mathrm{E}-$ 9D7B-BB25F40C3CA5\&filingTypeID=51. (March 4, 2019).

. 2018. "Lobbying Report". Accessed at https://soprweb.senate.gov/ index.cfm? event $=$ getFilingDetails\&filingID $=0216963 \mathrm{~A}-660 \mathrm{D}-46 \mathrm{Bo}-$ $\mathrm{AD} 14-21 \mathrm{ACoF} 7 \mathrm{~B} 3 \mathrm{CB} 3 \&$ filingTypeID=78. (August 4, 2019).

. 2019. "Lobbying Report". Accessed at https://soprweb.senate.gov/ index.cfm? event=getFilingDetails\&filingID $=27 \mathrm{~A} 73 \mathrm{~F} 68-621 \mathrm{D}-4 \mathrm{CD} 7-$ BBDA-D490D1F7D1DC\&filingTypeID=78. (March 4, 2019). . 2019. "Lobbying Report". Accessed at https://soprweb.senate.gov/ index.cfm? event=getFilingDetails\&filingID $=1 \mathrm{BA} 58 \mathrm{AB} 8-954 \mathrm{E}-4 \mathrm{AF} 2-$ 8178-BE8E8E6o6BA1\&filingTypeID=6o. (August 4, 2019).

Warren, Robert. 2019. "US Undocumented Population Continued to Fall from 2016 to 2017, and Visa Overstays Significantly Exceeded Illegal Crossings for the Seventh Consecutive Year". Center for Migration Studies. Accessed at https://cmsny.org/publications/essay-2017undocumented-and-overstays/.(February 20, 2019.)

Wilkinson, Francis. 2018. "Trump Is Making Americans More ImmigrantFriendly”. Bloomberg (December 18).

Williamson, Jeffrey G. 2005. The Political Economy of World Mass Migration: Comparing Two Global Centuries. Washington D.C.: The AEI Press.

Wright, Matthew, Levy Morris, and Citrin Jack. 2015. "Public Attitudes Toward Immigration Policy Across the Legal/Illegal Divide: The Role of Categorical and Attribute-Based Decision-Making." Political Behavior 38(1), 229-253. 
The convergence of public opinion and interest group lobbying and the disruption of the Trump administration in United States immigration policy $\mid 215$

Zolberg Aristide R., and Russell Sage Foundation. 2008. A Nation by Design : Immigration Policy in the Fashioning of America. New York, NY: Russell Sage Foundation.

[Received May 31, 2018; Revised Jun 17, 2019; Accepted Aug 6, 2019] 